\title{
Myopia and divergent squint in West Indian children
}

\author{
PETER EUSTACE \\ Birmingham and Midland Eye Hospital
}

With the large-scale immigration of West Indians into the United Kingdom, certain clinical entities associated with this group have become familiar to ophthalmologists here.

Crews (1963) reported from Birmingham on West Indian amblyopia and Rubinstein (1967) reviewed the retinal findings in the S.A. and S.C. haemoglobinopathies also as seen in Birmingham. A keratopathy appearing only in West Indians has also been described (Rice, Jones, and Ashton, 1968).

The purpose of this study was to confirm or deny the clinical impression that strabismus in West Indian children born in the United Kingdom displays a distinct pattern, and in particular that there is an increased incidence of myopia and divergent squint.

\section{Method}

All West Indian children currently attending the orthoptic departments of the Birmingham and Midland Eye Hospital and the Children's Hospital, Birmingham, are being considered; the study is continuing and has been widened to include other immigrant groups.

The children are seen either at routine attendance or by special appointment. A full ocular and orthoptic examination is carried out, including refraction under atropine. The parents are interviewed and their refractive error noted.

\section{Results}

To date I 8 West Indian children have been seen. Of these, 53 children were nonsquinters, having been referred principally by the school medical service for the investigation of poor vision, and interestingly, 37 of these children were found to be myopic. This study, however, concerns the group of 65 squinting children. Table I sets out general information about this group; 27 ( $4{ }^{1} \cdot 5$ per cent.) were myopic and eighteen $(27 \cdot 7$ per cent.)

Table I General infor-

mation regarding 65

squinting West Indian

children

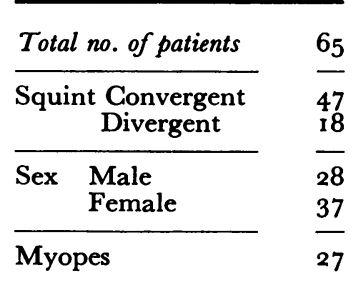


had a divergent squint. Any minus refractive error was regarded as myopia and any plus error as hypermetropia; since the numbers were small and for simplification, cylindrica $\tilde{F}_{5}$ error was reduced to its spherical equivalent. The refractive error of the group as a whole is compared with that of the convergent and divergent groups in the Figure.

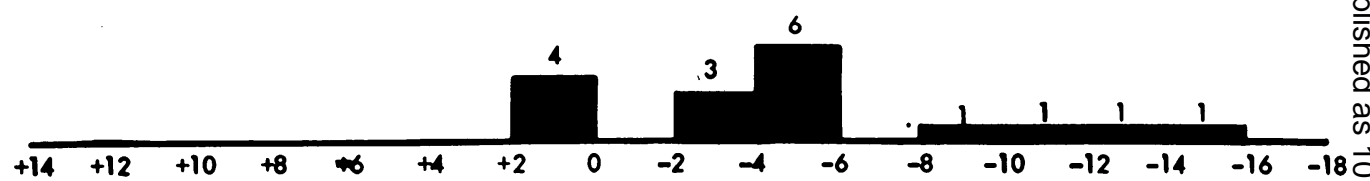

MEAN REFRACTIVE ERROR 17 WEST INDIAN CHILDREN WITH DIVERGENT SQUINT

(no information on one patient)

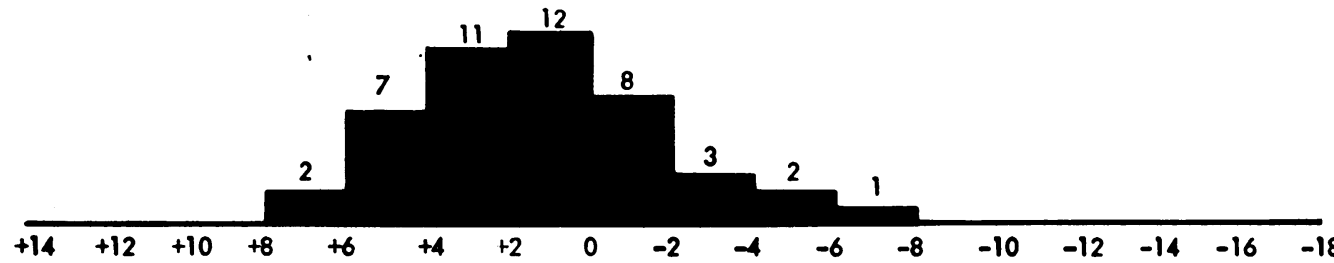

MEAN REFRACTIVE ERROR OF 46 WEST INDIAN CHILDREN WITH CONVERGENT SQUINT

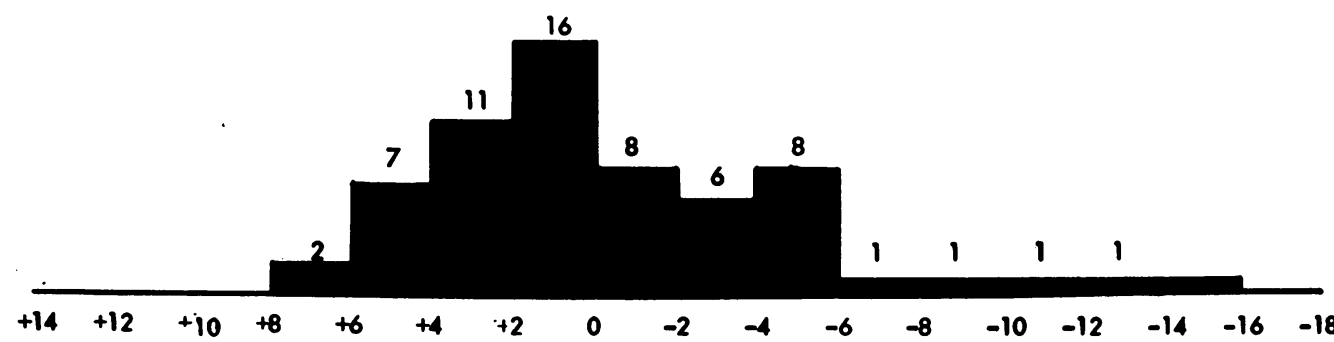

MEAN REFRACTIVE ERROR OF 63 WEST INDIAN CHILDREN WITH SQUINT

(no information on two patients)

FIGURE Refractive error in cases of divergent and convergent squint and in the group as a whole

Tables II and III set out the findings in the convergent and divergent squinters. Four teen ( $29 \cdot 8$ per cent.) of the convergent squinters and thirteen $(72 \cdot 2$ per cent.) of the divere gent squinters were myopes. The sex incidence of the myopes in both groups was roughl疋 equal.

Table IV shows the island of origin of the parents.

Amblyopia was present in twenty (30.8 per cent.) patients, and thirteen $(65$ per cent. of the children were anisometropic with more than 2 dioptres difference between the two eyes.

Seven of the myopes had parents with myopia and a family history of squint was obtained for two of the squinters. 
Table II Findings in West Indian children with convergent squint

Total no. of patients

Myopia

Sex Male

Female

\begin{tabular}{|c|c|}
\hline Types of convergent squint & $\begin{array}{l}\text { Fully accommodative } \\
\text { Fully accommodative with convergence excess } \\
\text { Partially accommodative } \\
\text { Constant }\end{array}$ \\
\hline Other incidental findings & $\begin{array}{l}\text { Ptosis } \\
\text { Microphthalmos }\end{array}$ \\
\hline Surgery & $\begin{array}{l}\text { No. of cases } \\
\text { Results } \begin{array}{l}\text { Cosmetic } \\
\text { Binocular single vision }\end{array}\end{array}$ \\
\hline Motor findings & $\begin{array}{l}\text { Normal extraocular muscles } \\
\text { Inferior oblique overaction } \\
\text { Bilateral inferior oblique overaction } \\
\text { Unilateral limitation of abduction } \\
\text { Bilateral limitation of abduction } \\
\text { Superior oblique tendon sheath syndrome }\end{array}$ \\
\hline Sensory findings & $\begin{array}{l}\text { Amblyopia } \\
\text { Binocular single vision }\end{array}$ \\
\hline
\end{tabular}

Table III Findings in West Indian children with divergent squint

\begin{tabular}{lllr}
\hline Total no. of patients & & 18 \\
\hline Myopia & & 13 \\
\hline Sex Male & & 5 \\
Female & & 13 \\
\hline Types of divergent squint & Duane type G & 1 \\
& Divergence excess & Mixed intermittent & \\
& Constant squint & \\
\hline Surgery & No. of cases & 1 \\
& Result Binocular single vision & 12 \\
\hline Motor findings & Normal extraocular muscles & 2 \\
& v"Exo" phenomenon & 1 \\
& Duane type G & 1 \\
& Inferior oblique overaction & 2 \\
\hline Sensory findings & Mixed defects of extraocular muscles & 4 \\
& Binocular single vision & 5 \\
\hline
\end{tabular}

\section{Discussion}

SEX RATIO

There is a considerable literature pointing out the equal sex incidence of myopia in its lower degrees, and most are agreed that there is an increased female incidence in the higher degrees (Wilson, 1913). The sex ratio of both squinters and myopes in this series shows a small female bias. 
Table IV Birthplace of parents of squinting and myopic children

\begin{tabular}{|c|c|c|}
\hline $\begin{array}{l}\text { Island of birth of } \\
\text { parents }\end{array}$ & $\begin{array}{l}\text { Of whole } \\
\text { group } \\
(\mathrm{I} 30)\end{array}$ & $\begin{array}{l}\text { Of } 2 \text { I } \\
\text { myopic } \\
\text { children (54) }\end{array}$ \\
\hline Jamaica & 88 & $3^{6}$ \\
\hline St. Kitts & 20 & 10 \\
\hline Barbados & 7 & 4 \\
\hline Trinidad & 2 & - \\
\hline Granada & 2 & 2 \\
\hline St. Vincent & 4 & 2 \\
\hline Anguilla & I & - \\
\hline Nevis & I & - \\
\hline Great Britain & 4 & - \\
\hline Ireland & i & - \\
\hline
\end{tabular}

RATIO OF GONVERGENT TO DIVERGENT SQUINT

Figures produced by Wesson (I96I) for the Birmingham Children's Hospital in the years I 949 to I 959 show convergent squint to be almost fifteen times as common as divergent squint. Morgan (I95I) produced similar figures in Cheltenham. However, convergent squint in this series was approximately only three times as common as divergent squint.

Since both Morgan and Wesson's figures related almost entirely to Caucasians, the West Indian group of children studied here have an incidence of divergent squint four times higher than a similar Caucasian group.

Females were affected twice as often as males and this relationship corresponds with that found in other studies of divergent squint (Cass, 1937).

\section{MYOPIA}

The overall incidence of myopia ( $4 \mathrm{I} \cdot 5$ per cent.) is broken down into an incidence of $72 \cdot 2$ per cent. for the divergent squinters and $29 \cdot 8$ per cent. in the convergent squinters.

It was originally suggested by Donders ( 1864 ) that the relationship between myopia and divergent squint paralleled that between hypermetropia and convergent squint, but this theory was later discounted.

In this series the incidence of myopia in divergent squint is twice that of myopia in convergent squint, so that at least in this study Donders's theory receives support.

A possible explanation for the high incidence of myopia in convergent squint is that there is simply a higher incidence of myopia in this group of children as a whole. Lagleyze (1913) gives a figure of only I 3 per cent. myopia for his series of squint in French school children.

RACIAL INGIDENCE OF MYOPIA

Racial differences in the pattern of refractive errors are well known. The Chinese, the Japanese, and the Jewish races all have a higher incidence of myopia than Europeans (Chan, 1953; Miyashita, I93 I Sorsby, 1934). Negroes as a race, however, are usually emmetropic (Johnstone and McLaren, I963) but the only study of West Indian school children (Van Trotsenburgh, 1908) reported a comparable incidence of myopia in both Dutch and West Indian children. 
A paper of particular interest and relevance is that of Young, Leary, Baldwin, West, Box, Harris, and Johnson (1969), who studied the pattern of refractive error in the Eskimo children of Barrow in Alaska. The incidence of myopia was 58.6 per cent., whereas that of the parent group was only $8 \cdot 4$ per cent. The generation of Eskimo children under study had been the first to be introduced to schooling and the American way of life, which suggests that environment plays a greater role in the development of myopia than heredity.

\section{AMB L Y O PIA}

This was present in 30.8 per cent. of the children at the time of the study and had received treatment. Naylor and Wright (1959), reviewing Manchester children with squints, found that the incidence of intractable amblyopia was i 4 per cent., about half that of our West Indian group of children.

In this study amblyopia occurred as commonly in divergent as in convergent squint.

Anisometropia was common, occurring in 65 per cent. of the amblyopes, and in all cases more than 2 dioptres separated the refractive error of the amblyopic eye from that of the normal eye.

\section{FAMILY HISTORY}

A family history of squint was obtained in 3.1 per cent. of the squinters and in 25.9 per cent. of the myopes, figures which do not support the idea that the environment affects the development of myopia.

\section{ISLAND OF ORIGIN}

The parents of the group as a whole came from a wide scatter of islands (only five were born in the British Isles) and a similar pattern was obtained for the parents of the myopes, so that no one island was producing the myopes. All the children in the group studied were born in the United Kingdom.

MOTOR FINDINGS

These displayed no particular trend.

\section{Summary and conclusions}

(I) West Indian children attending the Birmingham and Midland Eye Hospital and the Birmingham Children's Hospital with squint have a four times higher incidence of divergent squint than Caucasian children attending the same hospitals.

(2) The incidence of myopia in both convergent and divergent squint is also many times more than that found in a similar Caucasian group.

(3) Amblyopia appears to be twice as common in this group, possibly because of the frequently associated anisometropia.

I should like to thank the surgeons of the Birmingham and Midland Eye Hospital and the Birmingham Children's Hospital for permission and encouragement to study their patients, and staff of the Orthoptic Departments of both hospitals without whose assistance this study would not have been possible. 


\section{References}

CAss, E. E. (1937) Brit. J. Ophthal., 21, $53^{8}$

CHAN, E. (1953) Chin. med. F., 7r, 476

CREWs, s. J. (1963) Trans. ophthal. Soc. U.K., 83, 653

DONDERS, F. c. (1864) “Accommodation and Refraction of the Eye". New Sydenham Society,

London

JOHNStone, w. W., and McLAREN, D. s. (1963) Brit. J. Ophthal., 47, 95

LAGleyze, P. (1913) "Du strabisme". Rousset, Paris

MIYASHITA, s. (I93 I) Acta Soc. ophthal. jap., 35, 934

MORGAN, A. (1957) Brit. orthopt. F., I4, I I I

NAYLOR, E. J., and WRIGHT, A. G. (1959) Ibid., 16, Io9

Rice, N. S. C., JONES, B. R., and AShtON, N. (1968) Brit. F. Ophthal., 52, 865

RUBINSTEIN, K. (1967) Ibid., 51, 217

SORSBY, A. (1934) Trans. ophthal. Soc. U.K., 54, 459

TROTSENBURG, J. A. VAN (1908) Ned. T. Geneesk., I, 122 I

WESSON, M. E. (1961) Brit. orthopt. J., 18, I 14

wiLson, J. A. (1913) Glasgow med. F., 79, 250

YOUNG, F. A., LEARY, G. A., BALDWIN, W. R., WEST D. C., NOX, R. A., HARRIS, E., and JOHNSON, C,

(1969) Amer. 7. Optom., 46, 676 